\title{
Determination of Iron Content in Indigenous Vegetables in South West Nigeria
}

\author{
O. G. Dawodu ${ }^{1^{*}}$, J. O. Olanike ${ }^{1}$ and R. B. Akanbi ${ }^{1}$ \\ ${ }^{1}$ Department of Science Laboratory Technology, Federal Polytechnic Ede, Osun State, Nigeria.
}

Authors' contributions

This work was carried out in collaboration among all authors. Author OGD designed the study, performed the statistical analysis, wrote the protocol and wrote the first draft of the manuscript. Authors JOO and RBA managed the analyses of the study. All authors read and approved the final manuscript.

\section{Article Information}

DOI: $10.9734 / A R R B / 2020 / v 35 i 430209$ Editor(s):

(1) Dr. Viduranga Y. Waisundara, Australian College of Business \& Technology, Sri Lanka. Reviewers:

(1) Selina Ama Saah, University of Energy and Natural Resources, Ghana. (2) N. Umerah Nkemjika, University of Science and Technology, Nigeria. (3) Romer C. Castillo, Batangas State University, Philippines. Complete Peer review History: http://www.sdiarticle4.com/review-history/54907

Original Research Article

Received 02 January 2020

Accepted 06 March 2020

Published 24 May 2020

\section{ABSTRACT}

This study was done to determine the level of iron in selected indigenous vegetables (grown in Ede, Osun State, Nigeria) using colorimetric method. The six indigenous and three common ones selected for the study are; Basella alba (Amunututu), Ocimum gratissium (Efirin), Talinum fruticosum (Gbure), Amaranthus hybridus (Tete adayeba), Amaranthus hybridus (Tete olowojeja), Corchorus olitorius (Ewedu), Telfairia occidentalis (Ugwu), Celosia argentea (Soko) and finally Amaranthus hybridus (Tete). The vegetables were ashed and iron content of the vegetables was determined colorimetrically at $470 \mathrm{~nm}$. The results showed that, amongst the indigenous vegetables the iron concentration ranged from 0.094 to $0.66 \mathrm{ppm}$ with Amaranthus hybridus (Tete adayeba) and the Basella alba (Amunututu) recording the highest and lowest levels respectively. The common vegetables had iron levels ranging from 0.0304 to $0.703 \mathrm{ppm}$ with Amaranthus hybridus (Tete) recording the lowest level and Telfairia occidentalis (Ugwu) recording the highest level respectively. The findings showed that the sampled indigenous vegetables are a good source of iron in diet.

\footnotetext{
*Corresponding author: E-mail: dawgrace@yahoo.com, dawodu.olufunke@federalpolyede.edu.ng;
} 
Keywords: Diet; iron levels; leafy vegetables.

\section{INTRODUCTION}

Vegetables grow by cultivation and natural occurrence. Traditional vegetables are valuable sources of the nutrient with some having important medicinal properties [1]. Indigenous leafy vegetables are all plants, whose leaves, roots or fruits are acceptable and used as vegetables in the rural and urban population through traditions, custom and habit [2]. These vegetables are widely consumed, especially during the famine and natural disasters when cultivations of vegetables are not possible. Recently, indigenous vegetables have won some recognition through crop research at international regional and national institutions [3]. Leafy vegetables have been used through history to date [4]. According to Mwangi and Mumbai [5] most widespread and debilitating nutritional disorders, including birth defects, mental and physical weakened immune system blindness and even death have resulted from non consumption of fruits and vegetable habits. Hunger and malnutrition threaten millions of people in sub - Saharan Africa, yet the value of African traditional vegetables is not fully appreciated. Increased consumption of African leafy vegetables (ALVs) can have a positive effect on nutrition, health and economic wellbeing of both rural and urban populations [6].

In developing countries, nearly 16 million people die every year from preventable causes, and sixty percent of these deaths are from hunger and malnutrition. Most poor people who battle hunger, battle with malnourishment, especially vitamins and mineral deficiencies which results in stunted growth, weakness and heightened susceptibility to illness.

In Africa, the number of indigenous vegetable species is far greater than the exotic ones. The consumption of green leafy vegetables, which have the highest nutritional value adds to the nutritional status of poor rural and urban households [7]. Also, increased consumption of African indigenous vegetables enhances crop diversity, alleviates poverty and promotes food security [8]. However, the statuses of the crops, as well as their conservation, need to be addressed to ensure sustainable use [4]. Iron $(\mathrm{Fe})$ is the fourth most abundant element in the earth's crust and is an essential nutrient for plants [9]. Iron is an essential trace element, meaning a healthy diet must include this nutrient. An extremely important mineral for general well being and energy, iron is the essential element within the haemoglobin molecule, which carries the oxygen in every red blood cell. It also functions in myoglobin, a molecule that supplies oxygen to the muscles. Iron is required for proper myelination of spinal cord and white matter of cerebellar folds in the brain and is a cofactor for several enzymes involved in neurotransmitter synthesis [10]. Iron ferrin, stored as ferritin or haemosiderin and it is lost in sloughed cells and by bleeding. Iron is required for making $\mathrm{Hb}$ and it is a preoxidant which is also needed for microorganisms for proliferation.

Iron can be found in high amounts in liver and meats. Vegetable sources include leafy greens, nuts and seeds. Iron is especially abundant in pumpkin and sunflower seeds, raisins and prunes and wheat germ.

This study sought to determine the iron content of each indigenous vegetable and common ones.

\section{MATERIALS AND METHODS}

\subsection{Sample Collection and Authentication}

The vegetable samples were obtained from three different locations in Ede. The authentication was carried out at Department of Botany, Obafemi Awolowo University lle - Ife. The authenticated samples were Basella alba (Amunututu), Ocimum gratissium (Efirin), Talinum fruticosum (Gbure), Amaranthus hybridus (Tete adayeba), Amaranthus hybridus (Tete olowojeja), Corchorus olitorius (Ewedu), Telfairia occidentalis (Ugwu), Celosia argentea (Soko) and Amaranthus hybridus (Tete).

\subsection{Methods}

\subsubsection{Preparation of stock solution}

According to standard procedure as described by Narain \& llango [11]. Three stock solutions were made ready before the experiment and were stored in five $500 \mathrm{ml}$ neatly labelled standard flasks. Firstly, the $0.001 \mathrm{M} \mathrm{FeCl}_{3}$ stock solution was prepared by adding approximately $0.162 \mathrm{~g}$ of $\mathrm{FeCl}_{3}$ in $500 \mathrm{ml}$ distilled water followed by the addition of $5 \mathrm{ml}$ concentrated $\mathrm{HCl}$. The contents were diluted to $1 \mathrm{~L}$ and were mixed well before 
being transferred to the standard flask. This solution was only used for calibration purposes and was discarded after that. The $1.5 \mathrm{M} \mathrm{NH}_{4} \mathrm{SCN}$ solution was prepared by adding approximately $36.375 \mathrm{~g}$ of $\mathrm{NH}_{4} \mathrm{SCN}$ in $500 \mathrm{ml}$ distilled water. The contents were mixed well before being transferred to the standard flask. This solution was the basis of the colourimetry involved in the analysis and was used till the end of the experiment.

The $2 \mathrm{M} \mathrm{HCl}$ solution was prepared by adding $170 \mathrm{ml}$ of concentrated $\mathrm{HCl}$ to $500 \mathrm{ml}$ distilled water and diluting the solution to $1 \mathrm{~L}$ with distilled water. The contents were mixed well before being transferred to the standard flask. This solution was used for dilution purposes and served as the blank in the colorimetric analysis.

\subsubsection{Iron content determination}

Thiocyanate colorimetry was carried out using a colorimeter. The colorimeter worked on the principle of the Beer-Lambert law and was operated in the visible range of the spectrum. The colorimetric reagent used for the analysis was ammonium thiocyanate, for which the $\lambda$ max value obtained was $470 \mathrm{~nm}$. The basic reaction when thiocyanate reacts with iron (III) is as follows:

$\mathrm{Fe}_{3}+(\mathrm{aq})+6 \mathrm{SCN}-(\mathrm{aq}) \leftrightarrow\left[\mathrm{Fe}(\mathrm{SCN})_{6}\right]^{3-}(\mathrm{aq})$. The thiocyanate complex, $\left[\mathrm{Fe}(\mathrm{SCN})_{6}\right]^{3-}$ had a deep red colour and its intensity was directly related to the concentration of the solution. The colorimetric analysis was used for its simplicity, convenience and availability in the institute.

\subsubsection{Calibration curve}

Seven standard solutions were prepared each having a molarity of $0.5 \times 10^{-4} \mathrm{M}, 1 \times 10^{-4} \mathrm{M}, 1.5 \times 10^{-}$ ${ }^{4} \mathrm{M}, 2 \times 10^{-4} \mathrm{M}, 2.5 \times 10^{-4} \mathrm{M}, 3 \times 10^{-4} \mathrm{M}$ and $4 \times 10^{-4} \mathrm{M}$. The first solution was prepared by diluting $0.5 \mathrm{ml}$ of $0.001 \mathrm{M} \mathrm{FeCl}_{3}$ solution with $9.5 \mathrm{ml}$ of $2 \mathrm{M} \mathrm{HCl}$ solution.

Similarly, the corresponding solutions are made by diluting $1 \mathrm{ml}, 1.5 \mathrm{ml}, 2 \mathrm{ml}, 2.5 \mathrm{ml}, 3 \mathrm{ml}$ and 4 $\mathrm{m}$ of $0.001 \mathrm{M} \mathrm{FeCl}_{3}$ solution to $10 \mathrm{ml}$ by $2 \mathrm{M} \mathrm{HCl}$ solution.

After this, $5 \mathrm{~mL}$ of $1.5 \mathrm{M} \mathrm{NH}_{4} \mathrm{SCN}$ was added to each of the solution and mixed by swirling the test tubes. This step diluted the $10 \mathrm{ml}$ solution to $15 \mathrm{ml}$ causing the concentration to decrease by $2 / 3$ rd of its original molarity value. Thus, the values read by the colourimeter were for twothirds of the actual concentration. After adding $\mathrm{NH}_{4} \mathrm{SCN}$, the absorbance was measured immediately because absorbance value can be affected as the colour of the solution fades within $15-20$ minutes. $2 \mathrm{M} \mathrm{HCl}$ was used as the blank. Using these solutions, the concentration vs absorbance curve was plotted.

\subsubsection{Ashing of the samples}

According to the ashing procedure as described by $[11,12] .1-15 \mathrm{~g}$ of the edible portion of the food samples was weighed. They were finely chopped and charred using a clay pot and hot plate for the purpose of ashing. The weighed samples were charred and heated in a muffle furnace at 200$240^{\circ} \mathrm{C}$ for 3 hours. This step was carried out in a well-ventilated room. The samples were heated till a grayish ash was observed and then they were powdered using a mortar and pestle. After the samples were cooled, they were transferred to a small beaker of $100 \mathrm{ml}$ capacity and the iron (III) in the ash was dissolved in $10 \mathrm{ml}-30 \mathrm{ml}$ of $2 \mathrm{M} \mathrm{HCl}$. The ash solution was stirred using a glass stirring rod for about 5 minutes and then filtered using what man filter paper.

\subsubsection{Analysis of the samples}

Five $\mathrm{ml}$ of the filtered sample was transferred to a test-tube and then $5 \mathrm{ml}$ of $1.5 \mathrm{M} \mathrm{NH} \mathrm{NCN}_{4} \mathrm{SCas}$ added. The mixture was stirred by swirling the test tube. The absorbance was measured without delay as the colour of the solution faded within 15-20 minutes. The solution concentration was halved by adding $5 \mathrm{ml}$ of $\mathrm{NH}_{4} \mathrm{SCN}$. The $2 \mathrm{M} \mathrm{HCl}$ solution served as the blank. The absorbance values were measured for all the 9 samples.

\section{RESULTS AND DISCUSSION}

Iron is important in the structure and function of red blood cell and deficiency leads to iron deficiency anemia, a common health problem in many developing tropical countries. African indigenous vegetable could be used in alleviating this problem as they have higher iron content that can meet daily iron content [13]. It is also an accepted that leafy vegetables are rich sources of micronutrients of which iron is of [14].

The iron content in a total of nine vegetables samples was analyzed using the thiocyanate colorimetric technique. The results showed a good quantity of iron in the Fluted Pumpkin $(U g w u)$ and African Spinach (Efo tete). The least 
iron was available in the Malabar spinach (Amunututu). Iron deficiency individuals may improve their dietary iron intake, according to the Recommended Daily Intake (RDI) of iron, by following a diet containing iron-rich vegetables food sources like Efo tete and Ugwu. The iron concentration of these vegetables unravels a high concentration of iron [15]. WHO records the fact that children, women of reproductive age and pregnant women are most vulnerable to the micro-nutrient iron deficiency which subsequently leads to anemia [16]. Hence, they need food with high iron content, the RDI for pregnant women is $14.7 \mathrm{mg}$, while for children it ranges between
13.7 to $16.3 \mathrm{mg}$ (https://ods.od.nih.gov). When these green leafy vegetables with enough iron content are eaten in dishes, there is no need for iron supplements. There is a risk of iron toxicity when iron supplements are over - dosed which may results in damage to liver an pancreas, and even sudden death in young children [17]. There is obvious under-utilization of indigenous vegetables [18], the world over, surprisingly Africa tops that list. There is the aggressive need to encourage use of such vegetables as they are easily cultivated within localities and access to them will prove no threat to the general populace.

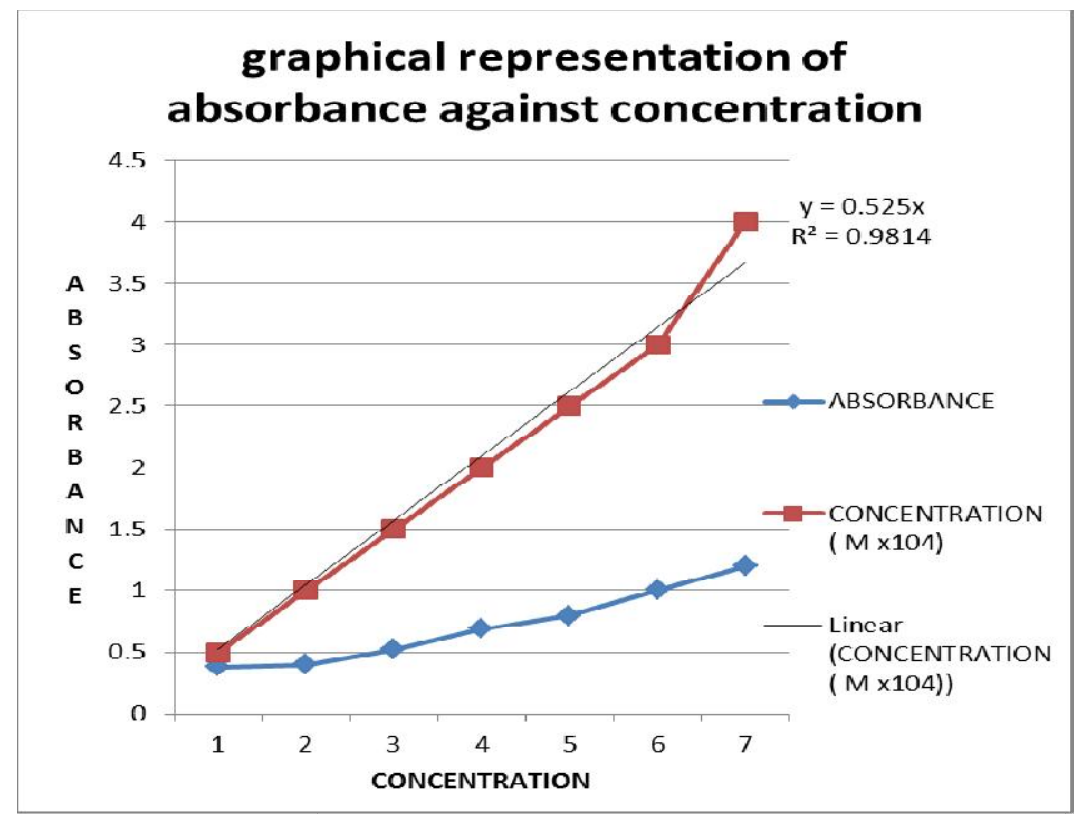

Fig. 1. Calibration curve used for the study

Table 1. Fe concentration in indigenous vegetables found in south west Nigeria

\begin{tabular}{ll}
\hline Vegetables & Concentration (ppm) \\
\hline Amunututu (Malabar Spinach) & 0.0945 \\
Ewedu (Jute Mallow) & 0.1575 \\
Gbure (Water leaf) & 0.1942 \\
Efirin (Scent leaf) & 0.3071 \\
Tete olowojeja & 0.3307 \\
Tete adayeba & 0.6667 \\
\hline
\end{tabular}

Table 2. Showing the Fe concentration in common vegetables

\begin{tabular}{ll}
\hline Vegetables & Concentration (ppm) \\
\hline Tete (African Spinach) & 0.3045 \\
Soko (Lagos spiinach/quail grass & 0.252 \\
Ugwu (Fluted punpkin) & 0.7035 \\
\hline
\end{tabular}




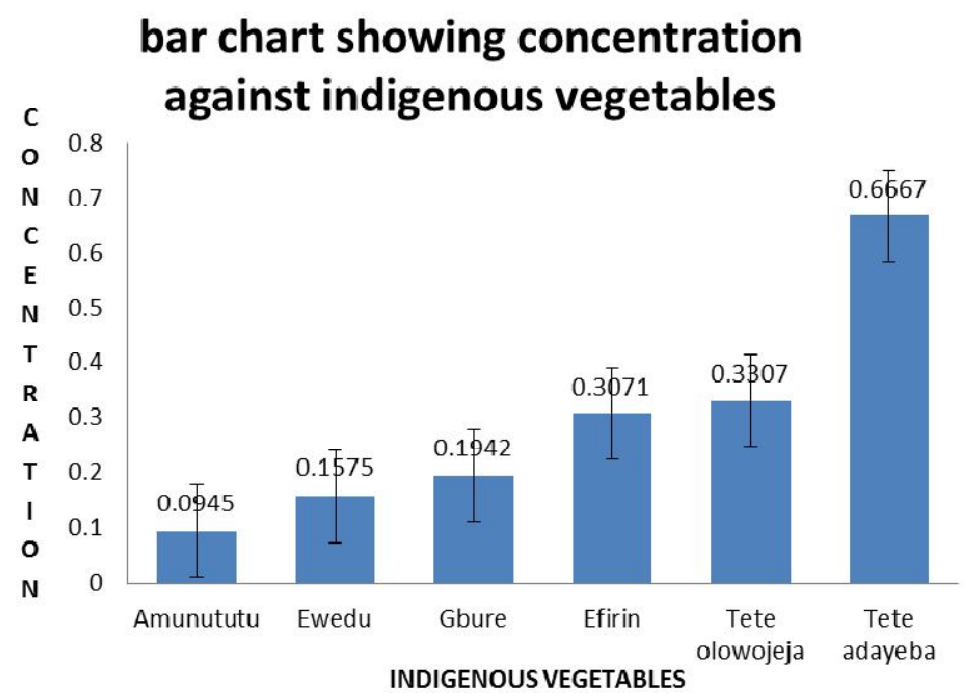

Fig. 2. Concentration of iron in indigenous vegetables

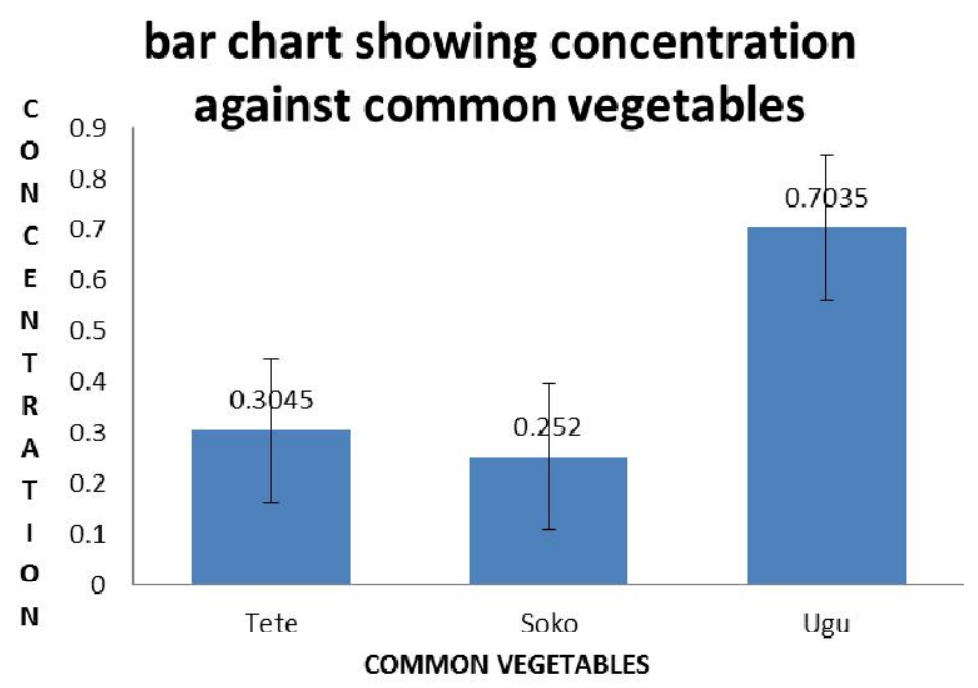

Fig. 3. Iron content in common vegetables

\section{CONCLUSION}

The present study revealed that the selected African indigenous vegetables are a good source of iron. Further studies on other nutrient should be done on the indigenous vegetables. This will help the consumers in obtaining information and promoting knowledge about high value of nutrients- rich indigenous vegetables could potentially address some health challenges. Increasing the production of indigenous vegetables and informing people how to prepare vegetables to gain maximum values will help ensure low cost nutrients reach vulnerable populations and enhance food and nutrition.

\section{COMPETING INTERESTS}

Authors have declared that no competing interests exist.

\section{REFERENCES}

1. Nesamvuni C, Steyn NP, Potgieter MJ. Nutritional value of wild, leafy plants consumed by the Vhavenda. South African Journal of Science. 2001;97:51-60.

2. Redzic SJ. Wild edible plants and their traditional use in the human nutrition in Bosnia-Herzegovina. Ecology of Food and Nutrition. 2006;45(3):189-232. 
3. Cernanisky R, Chadha J, Stewart RH. The rise of Africa's super vegetables; 2015.

4. Vorster IHJ, Jansen Van Rensburg WS, Ventor SSL. The importance of traditional leafy vegetables in South Africa. African Journal of Food and Agricultural Nutrition and Development. 2007;7(4):1-13.

5. Mwangi S, Mumbi K. African leafy vegetables evolves from underutilized species to commercial cash crops. Research Workshop on Collective Action and Market Access for Smallholders. Cali Colombia; 2006.

6. Abukutsa M, Obel-Lawson. African indigenous vegetables in Kenya: Strategic repositioning in the hoticultural sector: Inaugural lecture. Jomo Kenyatta University of Agriculture and technology, Nairobi, Kenya; 2010.

7. Chadha ML, Oluoch MO. Home-based vegetable and other strategies to overcome micronutrient malnutrition in developing countries. Food Nutrition and Agriculture. 2003;32:17-21.

8. Barry IN, Jaenicke H, Pichop GN, Virchow D. Production and marketing of African indigenous vegetables in the Arumeru district of Tanzania: Assessing post harvest loss and processing potentials. International Society for Horticultural Science (ISHS) Acta Horticulturae 806: International Symposium on Underutilized Plants for Food Security, Nutrition, Income and Sustainable Development; 2008.

9. Marschner H, Kirkby EA, Cakmak I. Effect of mineral nutritional status on shoot-root partitioning of photoassimilates and cycling of mineral nutrients. Journal of Experimental Botany. 1996;47:1255-1263.

10. Soetan KO, Olaiya $\mathrm{CO}$, Oyediran EO. The importance of mineral elements for humans, domestic animals and plants: $A$ review. African Journal of Food Science. 2010;4(5):200-222.

11. Narain $R$, llango $V$. Analysis of iron content in selected vegetarian food items in Dubai, UAE. International Journal of Science, Environment and Technology. 2015;4(3): 543-552.

12. Association of Official Analytical Chemists $(A O A C)$. Official methods of analysis. $15^{\text {th }}$ Ed. Washington, DC. 1990;123.

13. Habwe FM, Schippers H, Burkill. Copper and ascorbic acid content of cooked African indigenous vegetables. International Research and Food Security, Natural Resource Management and Rural Development. Tropentog, Zurich, Switzerland; 2010.

14. Nnamani CV, Oselebe HO, Okporie EO. Ethnobotany of indigenous leafy vegetables of Izzi Clan, in Ebonyi State, Nigeria. In: Proceedings of $20^{\text {th }}$ Annual National Conference of Biotechnology Society of Nigeria. 2007;111-114.

15. Adenipekun CO, Oyetunji OJ. Nutritional values of some tropical vegetables. Journal of Applied Biosciences. 2010;35: 2294-2300.

16. Gillespie S. Major issues in the control of iron deficiency. Ottawa, The Micronutrient Initiative and United Nations Children's Fund; 1998.

17. Estelle L, Kave M. Plants and Society Second Edition. The McGraw-Hill Companies, Inc. 1999;161-175.

18. Oselebe HO, Nnamani CV, Agbatutu A. Assessment of nutritional values of three underutilized indigenous leafy vegetables of Ebonyi State, Nigeria. African Journal of Biotechnology. 2009;8(9):2321-2321.

(c) 2020 Dawodu et al.; This is an Open Access article distributed under the terms of the Creative Commons Attribution License (http://creativecommons.org/licenses/by/4.0), which permits unrestricted use, distribution, and reproduction in any medium, provided the original work is properly cited.

Peer-review history:

The peer review history for this paper can be accessed here: http://www.sdiarticle4.com/review-history/54907 